\title{
Limnic Condition In Rheotrhopic Peat Type As the Origin of Petai Coal, Central Sumatra Basin, Indonesia
}

\author{
Budi Prayitno ${ }^{1, *}$ \\ ${ }^{1}$ Geological Engineering, Universitas Islam Riau
}

* Corresponding Author: budiprayitno@eng.uir.ac.id

Received: Oct 1, 2016. Revised : 15 Nov 2016, Accepted: Nov 20, 2016, Published: 1 Dec 2016

DOI : $10.24273 /$ jgeet.2016.11.9

Abstract

Petrographic coal is the study of organic and inorganic components of bearing coal formation. This study aims to determine the composition, depositional facies, type and stage of the genesis of coal in the area of research. This research method using a diagram approach Diessel, 1986, Calder et al., 1991 to determine the depositional facies and peat ecosystems formation of coal carrier. Microscopic observations using Carl Zeiss Microscope and Point Counter Model F was conducted to determine the micro-organic components of coal.

Based on microscopic investigation of the overall sample average abundance maceral vitrinite reached $66.3 \% 30.32 \%$ mineral matter, maceral liptinite $3: 26 \%$ and to absent maceral inertinit no indicates oxidation process that occurs during the decomposition of organic matter. Syngenetic depositional pyrite component type spread sporadically on the surface of the coal seam in the form frambiodal and particulates. Facies deposition of coal based on the calculation of tissue prevetion index versus gelification index show faises limnic while the calculation of ground water index versus vegetation index show atmosphere rheotropic mires (correlation +) supported the absence maceral inertinit and funginite, hypothesized water level in stable condition was high watertable during the decomposition process takes place in an atmosphere ph 6-8 and eh balanced. Average rate comparison gelifikasi the preserved tissues of plant cells (tellocolinite) is smaller than the $23.6 \%$ plant cell tissue is not preserved (desmocollinite) amounted to $52.6 \%$ indicated from plants of the type herbaceous plant.

Keywords: Coal, Depositional, Ground Water Index, Vitrinite.

\section{INTRODUCTION}

\subsection{BACKGROUND}

The astronomical part of Indonesia is at $0^{\circ}$ $0^{\prime} 00^{\prime \prime}-10^{\circ} 00^{\prime} 00^{\prime \prime} 0^{\prime} 00^{\prime \prime} \mathrm{LU}$ and $0^{\circ}-10^{\circ} 0^{\prime} 00^{\prime \prime} \mathrm{LS}$ separated by the equator and $90^{\circ}$ occupy $0^{\prime} 00^{\prime \prime} \mathrm{BB}$ - $140^{\circ} 0^{\prime} 00^{\prime \prime} B T$. Indonesian region based on geographical conditions has a tropical climate and is at the Eastern hemisphere. In Indonesia every year only changing two seasons, the rainy season and dry season. In general, the intensity of peat accumulation is affected by the tropical climate (Dehmer, 1993;. Grady et al, 1993; Esterle and Ferm, 1994; Hawke et al., 1999).

Climate, geology, vegetation and hydrological regime significantly determine the accumulation of peat and its associated facies including the composition of maceral. The latter can be used for reconstruction of the peat accumulation. Hydrological regime and vegetation type influencing the peat accumulation have commonly been indicated with groundwater index (GWI) and vegetation index (VI), respectively (Calder et al., 1991). GWI can be used to show the development of paleo-mires as well as their type varying from rheotrophic to ombrotrophic mires (e.g. Widodo, 2008; Amijaya and Littke, 2005). The degree of preservation of peat deposit has commonly been reconstructed by tissue preservation index (TPI), whereas, the relative dryness (telmatic) and wetness (limnic) of the peat-forming conditions by gelification index (GI) (e.g. Diesel, 1986; Lamberson et al., 1991).

In the object of this study part of the lower members of Telisa formation (early to middle Miocene) is investigated with respect to its maceral composition. The depositional environments relating to the degree of preservation, vegetation type, hydrological regime and wetness of the paleo-mire has been reconstructed.

\subsection{GEOLOGICAL SETTING}

Location research based on geological framework of Sumatra in Back Arc Central Sumatra Basin. whereas the development tektonostratigrafi Central Sumatra Basin can be described as the following stages:

Pre-Rift stage (Eocene); Sediments of the Pre-Rift stage are relatively poorly represented in Sumatra, but are more common elsewhere in Sundaland. in central Sumatra basin it can be seen from the presence of limestones and conglomerates 
Nummulitic Early Tertiary and Mélanges deposition (van Bemmelen 1949; Budhitrisna \& Andi Mango 1990; Samuel et al. 1997). Horst and Graben Stage (latest Eocene-Oligocene) In the late Eocene, or earliest Oligocene, continental margin sedimentation was brought to an end by the development of horst and graben structures throughout Sundaland. A similar sequence of events occurred not only in Sumatra, but also in many other areas, including the Java Sea, the Gulf of Thailand and the South China Sea. Sediment formation in Central Sumatra represented by Pematang and Kelasa Formation. Transgressive stage (Late Oligocene-Mid-Miocene) Following the change in tectonic regime in the Late Oligocene the whole region underwent regional subsidence in a sag phase, the effects of which extended well to the east of Sumatra into Malaysia. At the same time the arc system of Sumatra started developing and the area of the Barisan Mountains became an important source of sediments for the forearc and backarc basins. The rate of subsidence was greater in the backarc area than in other areas. Initially sedimentation outpaced the rate of subsidence, with sediments transported over greater distances, so that the basins were filled with fluvial units which extended well beyond the margins of the original rift basins to rest unconformably on the basement horsts. In Central Sumatra Basin Sediment from Sihapas Group consists of several formations; Lakat formations, defined by De Coster (1974) and the Menggala formation, defined by Mertosono \& Nayoan (1974). Maximum Transgression Stage(Mid-Miocene) The maximum transgression of Sumatra in the MidMiocene is not distinguished here as a distinct tectono-stratigraphic stage, but this term is often used to indicate formations of maximum marine shale deposition and minimum clastic influx. In the maximum transgressive phase, subsidence outpaced sedimentation and the sea gained access to almost the whole area. In the central part of the basin the Baong consists almost entirely of shale with one significant sandstone incursion, from the Malacca Platform to the east. This sandstone is of N12-14 (Mid-Miocene) age and has been called the 'Middle Baong Sand' in this area. Cameron et al. (1980) mentions the "Lower Baong Sand" is equivalent to the top of the Formation Ombilin, Telisa and Gumai in North and Central Sumatra basin. The Middle Baong Sandstones and the Upper Baong Shale by Mulhadiono et al. (1978, 1982), is part of the regression phase. Regressive Stage (Mid-Miocene-Present) in the Mid-Miocene, regional sag in Sumatra slowed down. While the forearc and backarc basins continued to subside, the Barisan Mountains emerged and became an important source of sediments. In the backarc basins from the late Mid-Miocene onwards turbiditic sandstones become an increasing component in the deep water formations. the peak activity and erosion of mountains row appointment lasts for Late Pliocene accompanied by intense volcanic activity along with the deposition of Minas Formation.

\section{METHODS}

The coal samples were then crushed to a maximum size of $1 \mathrm{~mm}$ and placed in resin blocks. The sample blocks were polished with a specified polisher. Microscopic investigation was carried out with a Carl Zeiss Microscope and Point Counter Model $\mathrm{F}$ was conducted to determine the microorganic components of coal. During maceral analysis, 500 points with a minimum distance of $0.2 \mathrm{~mm}$ between each point were counted from the polished sections. The maceral composition is expressed as percent (\% volume). Maceral classification used in this study refers to ICCP (2001). Mean random huminite reflectance measurements were performed on the surface of huminite particles under oil immersion. Fifty points of huminite reflectance were made on each sample.

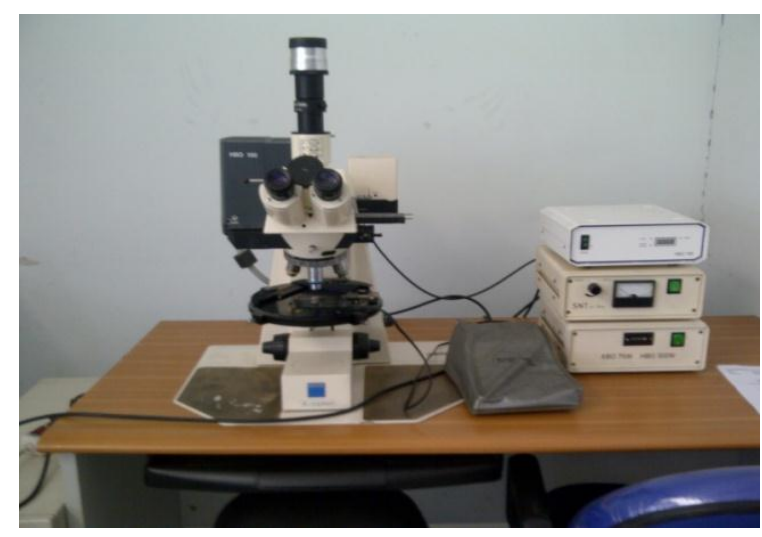

Figl. Carl Zeiss Microscope and Point Counter Model F with $500 \times$ magnification

Depositional environments of the petai coal were reconstructed based on the maceral composition. Some indices namely tissue preservation index (TPI) and gelification index (GI) according to Diessel (1986) and Lamberson et al. (1991) were determined. The indices were applied to investigate the degree of humification and the wetness of the paleo-mires. Vegetation index (VI) and groundwater index (GWI) based on Calder et al. (1991) were also calculated. The indices were used for the reconstruction of the type of paleomires developed in the deltaic basin. The indices were calculated by the following formulae. 


$$
\begin{gathered}
\text { TPI }=\frac{\text { Humotelinite }+ \text { Teloinertinite }}{\text { Humodetrinite }+\begin{array}{c}
\text { Humocollinite }+ \text { Inertodetrinite }+ \\
\text { Geloinertinite }
\end{array}} \\
\text { GI }=\frac{\text { Huminite }+ \text { Geloinertinite }}{\text { Inertinite (except Macrinite) })} \\
\text { GWI }=\frac{\text { Humocollinite }+ \text { Minerals }}{\text { Ulminite }+ \text { Humodetrinite }} \\
\text { Ulminite }+ \text { Fusinite }+ \text { Telogelinite }+ \text { Semifusinite }+ \\
\text { Suberinite }+ \text { Resinite }
\end{gathered}
$$

Fig 2. Formulae for measurement of TPI, GI, GWI, and VI

\section{RESULT}

Investigation under the microscope of the overall sample average abundance maceral vitrinite reached $66.3 \% 30.32 \%$ mineral matter, maceral liptinite $3.26 \%$ and Inertinit maceral absence indicates no oxidation process that occurs during decomposition of organic material. Maceral desmocollinite composition as the main coal in the study area followed by maceral densinite and tellocolinite respectively $45-68 \%$ 34-36\%and 19 $21 \%$ Based on the comparison of the above composition can be interpreted structure of plant origin low density easily decomposed. Decomposition of organic materials can be perfect if the peat layer is always in wet conditions or underwater. While maceral resinite and cuntinite abundant on the surface of the coal samples which indicate many species of plants contain cellulose, maceral species is very easily digested by aerobic bacteria and tissue composed of epidermis. Pyrite component based on the distribution pattern included in the depositional syngenetic is spread sporadically on the surface of the coal seam in the form of particulate and frambiodal

he presence of pyrite in the form frambiodal indicate the level of water surface of the peat layer was far above / high water table with no presence maceral funginite supported. Maceral funginite only be present if the peat layers that are in unfavorable humidity conditions and water level slightly above the peat layer. While maceral corpogelinite is relatively rare, there were only $0.6 \%$ occupy the sample composition 4P / 1/16. While the composition of the present tellocolinite as a comparison between maceral preserved maceral vitrinite is not preserved indicates the degree of gelifikasi quite instrumental in the process of decomposition of peat. While the composition of the present tellocolinite as a comparison between maceral preserved maceral vitrinite is not preserved indicates the degree of gelifikasi quite instrumental in the process of decomposition of peat. Coal facies interpretation is based on the calculation tissue reindexs prevention versus gelification reindexs indicate conditions transgresive limnic phase. Supporting data on which to base is not the presence of funginite above the sample surface coal polishes, maceral funginite only be present if the peat layer is at water level slightly above the peat layer. The presence of pyrite in the form frambiodal syngenetic also provide evidence of water level far above the surface of the peat layer. Sedimentation pattern formation of coal carrier complement the data supporting the form of intercalation of clays with sandstone rock is very smooth - smooth insertion of coal. While the calculation result reindexs versus groundwater vegetation indexs indicate the type rheotrhopic mires. Peat swamps with rheotrhopic atmosphere allows the water supply can be derived from surface water and groundwater that is likely peat layer is always in wet conditions.

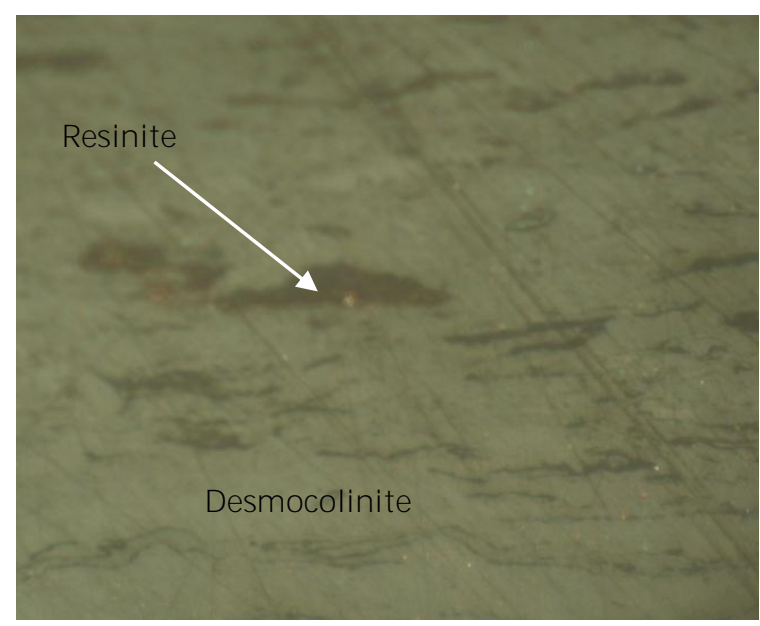

Fig 3. Resinite associated with desmocolinite in coal, reflectant white light, 500x. Sample 6105/16.

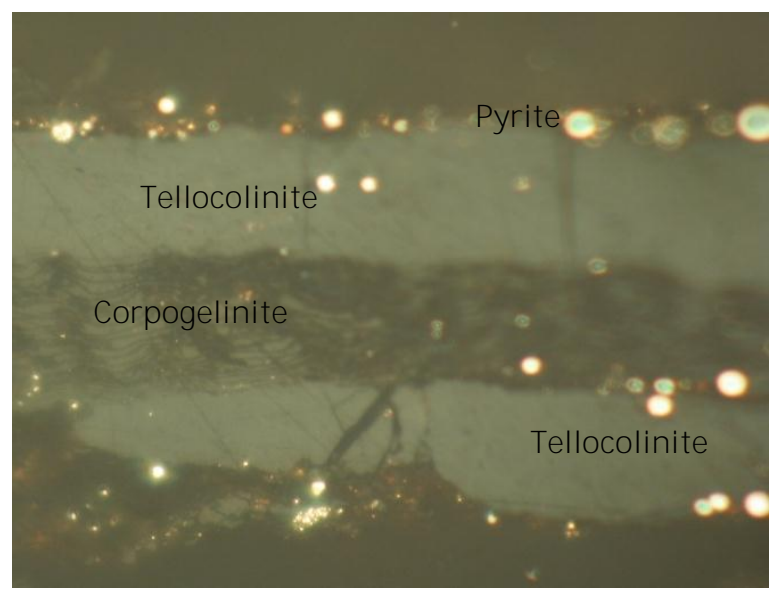

Fig 4. Corpogelinite and pyrite associated with desmocolinite in coal, reflectant white light, 500x. Sample 6103/16. 


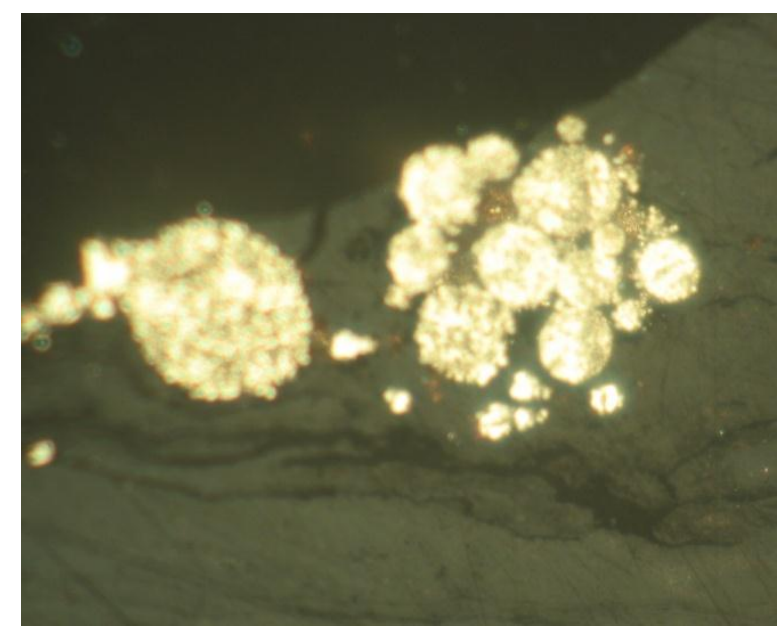

Fig 5. Pyrite framboidal associated with desmocolinite in coal, reflectant white light, 500x. Sample 6105/16.

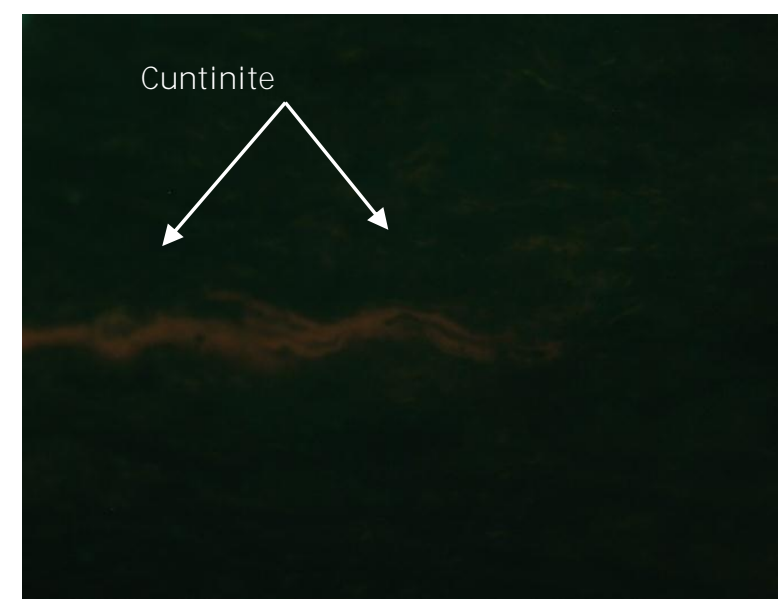

Figure 6. Pyrite and cutinite associated with densinite in coal, reflectant white flouresance, 500x. Sample 6102/16

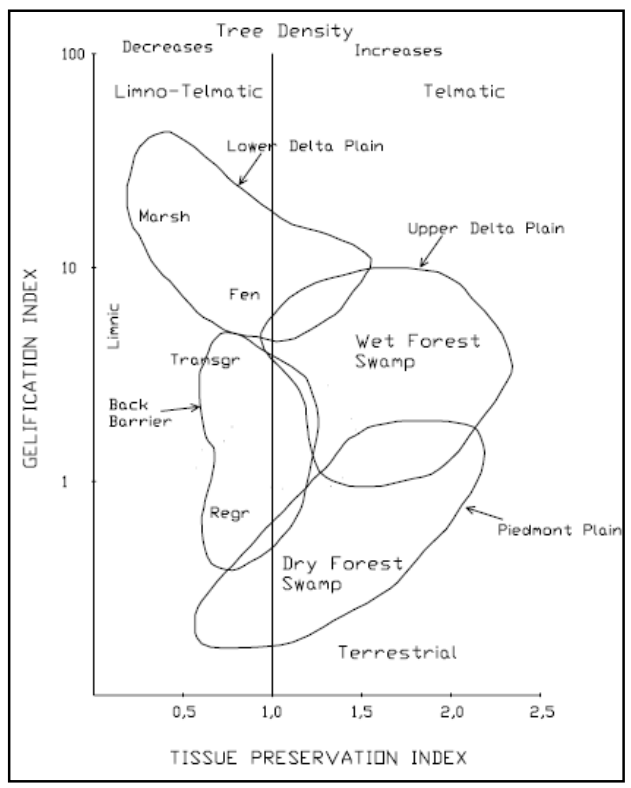

Figure 7. Diagram TPI vs GI

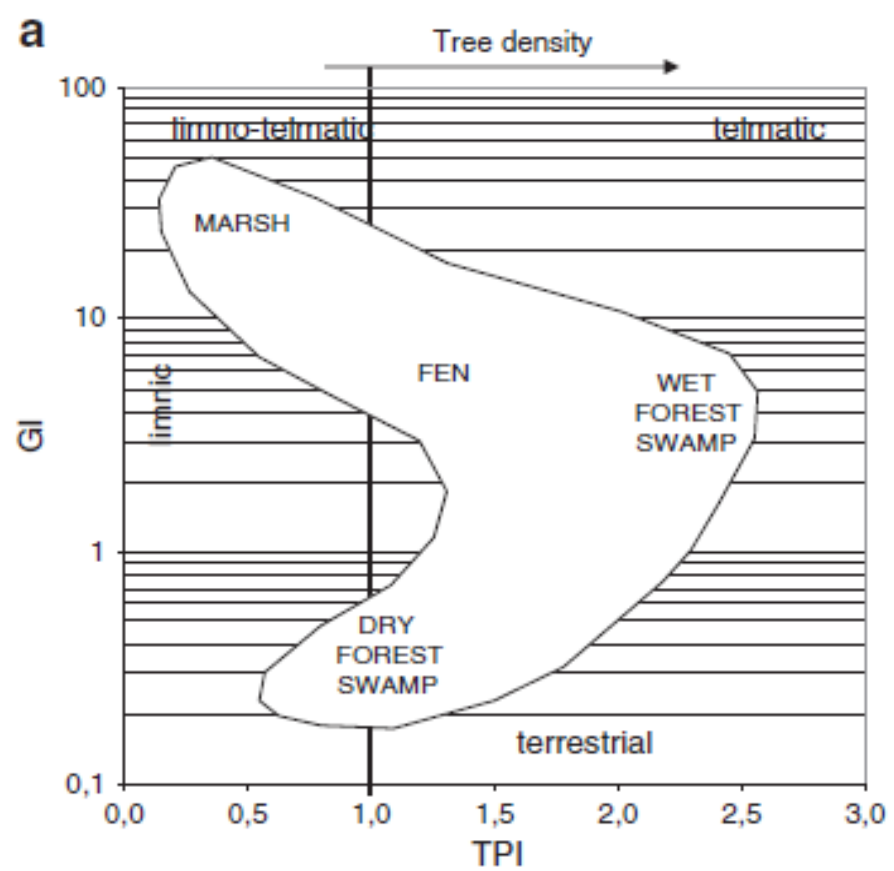

Fig 8. Diagram TPI vs GI for detemine depositional environtment

b

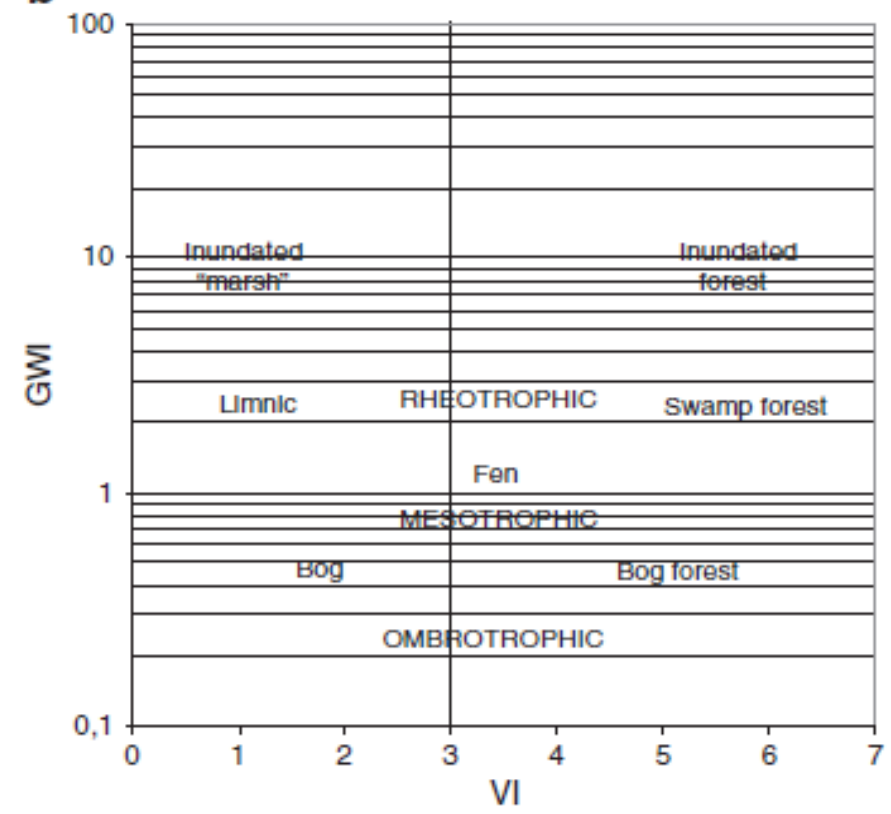

Fig 9. Diagram VI vs GWI 


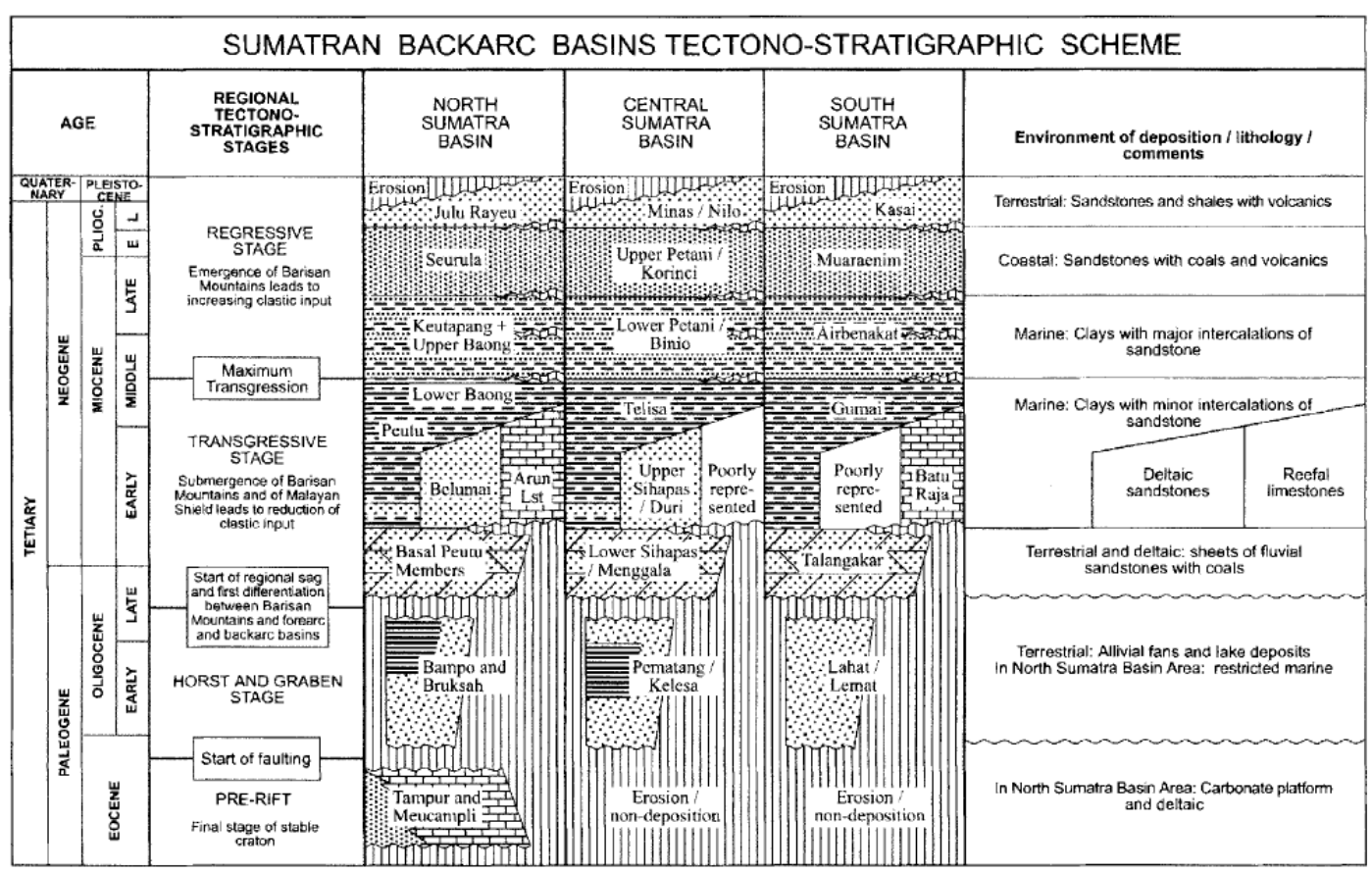

Fig. 10. Generalized tectono-stratigraphy of \{he Tertiary in the backarc basins of Sumatra. The diagram is highly simplified as most units interfinger and most boundaries

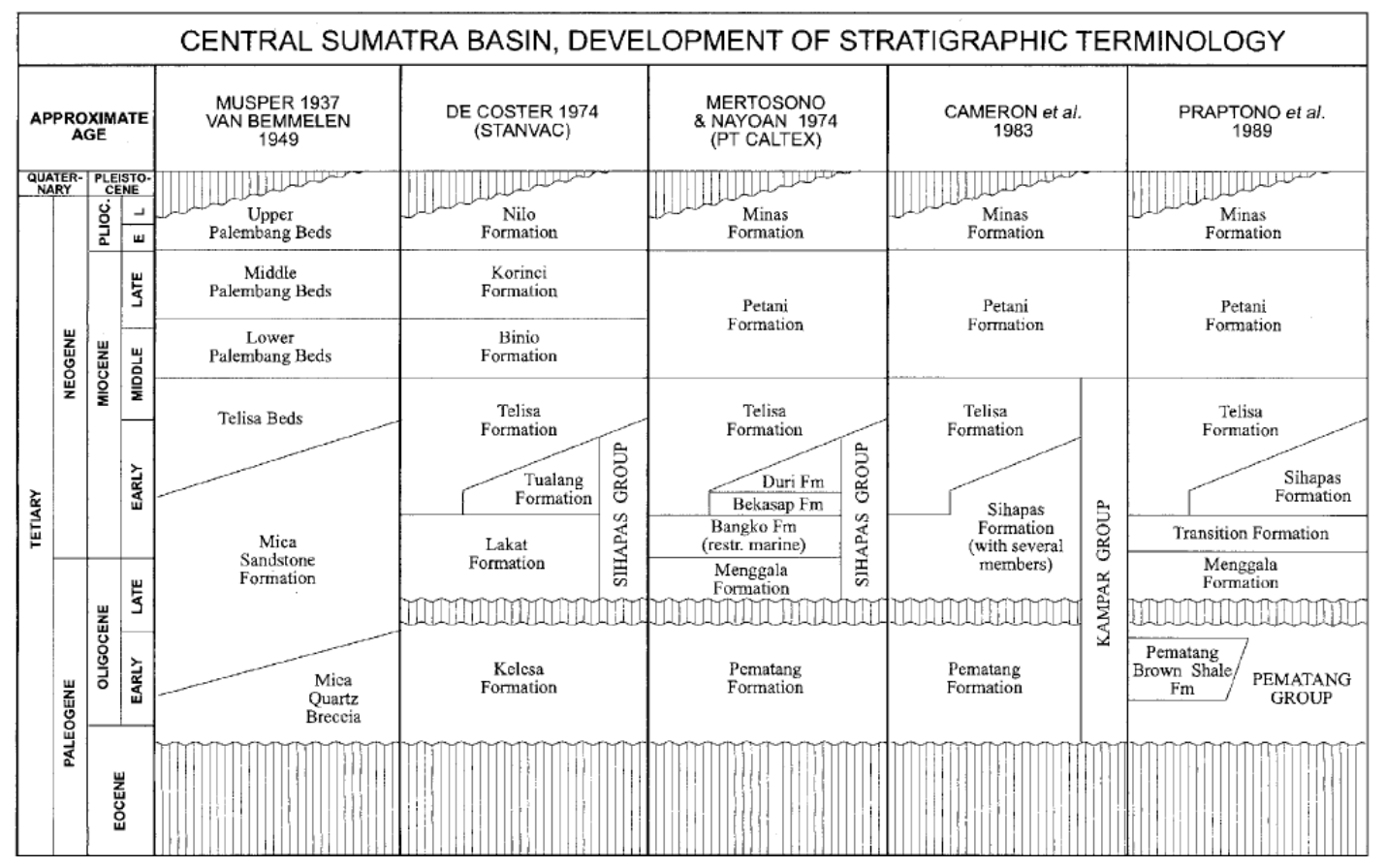

Fig. 11. The development of the stratigraphic terminology for the Tertiary of the Central Sumatra Basin. 


\section{Komposisi Maseral Batubara (\%}

\begin{tabular}{|c|c|c|c|c|c|c|}
\hline Maseral Group & Sub Maseral & Maseral & $1 \mathrm{P} / 1 / 16$ & $2 \mathrm{P} / 1 / 16$ & $3 P / 1 / 16$ & $4 \mathrm{P} / 1 / 16$ \\
\hline & Telovitrinite & Telocollinite & - & 11.0 & 11.0 & 27.0 \\
\hline \multirow{4}{*}{$\begin{array}{l}\text { VITRINITE } \\
\text { (HUMINITE) }\end{array}$} & Detrovitrinite & Densinite & 16.0 & 21.0 & 18.0 & 1.0 \\
\hline & & Desmocollinite & 20.4 & 26.0 & 23.4 & 60.4 \\
\hline & $\begin{array}{l}\text { Gelovitrinite } \\
\text { (Humocolinite) }\end{array}$ & Corpogelinite & - & - & - & 0.6 \\
\hline & & Sporinite & - & - & - & - \\
\hline \multirow[t]{2}{*}{$\begin{array}{l}\text { LIPTINITE } \\
\text { (EXINITE) }\end{array}$} & - & Cutinite & 1.6 & 1.0 & & 2.6 \\
\hline & & Resinite & 1.6 & 1.6 & 2.6 & 2.0 \\
\hline \multirow[t]{2}{*}{ INERTINITE } & - & Funginite & - & - & - & - \\
\hline & & Oksida & - & - & - & - \\
\hline $\begin{array}{l}\text { MINERALS } \\
\text { MATTER }\end{array}$ & - & Pyrite & 32.4 & 28.4 & 34.0 & 6.4 \\
\hline & & Clay & 28.0 & 11.0 & 11.0 & - \\
\hline
\end{tabular}

Table 2. Result Anal isis of Vitrinite Reflectance

Reflectansi Vitrinite Result

\begin{tabular}{ccccccc}
\hline No & No Sampel & $\begin{array}{c}\text { Standar } \\
\text { Deviation } \\
(\%)\end{array}$ & $\begin{array}{c}\text { Max } \\
\text { Reflectane } \\
(\%)\end{array}$ & $\begin{array}{c}\text { Min } \\
\text { Reflectane } \\
(\%)\end{array}$ & $\begin{array}{c}\text { Mean } \\
\text { Reflectane }(\%)\end{array}$ & Rank Coal \\
\hline & & & & & & \\
1 & $2 \mathrm{P} / 1 / 16$ & 0.02 & 0.54 & 0.47 & 0.50 & Sub-bituminous A \\
2 & $3 \mathrm{P} / 1 / 16$ & 0.02 & 0.56 & 0.50 & 0.52 & Sub-bituminous A \\
3 & $4 \mathrm{P} / 1 / 16$ & 0.02 & 0.62 & 0.55 & 0.58 & Sub-bituminous A
\end{tabular}

Value of TPI andGI Maseral Analysis result

\begin{tabular}{cccccccc}
\hline No & No Sampel & TPI & GI & Coal Fasies & GWI & VI & $\begin{array}{c}\text { Paleo-enviro } \\
\text { Calder et al., 1991, }\end{array}$ \\
\hline & & & & & & & \\
1 & $2 \mathrm{P} / 1 / 16$ & 0.11 & 1 & Limnic & 3.581 & 0.423 & Rheotrophic \\
2 & $3 \mathrm{P} / 1 / 16$ & 0.5 & 1 & Limnic & 4.090 & 0.47 & Rheotrophic \\
3 & $4 \mathrm{P} / 1 / 16$ & 0.127 & 1.006 & Limnic & 0.6 & 0.45 & Rheotrophic
\end{tabular}


$\sum$ Composition Group of Maseral and Mineral Matter

\begin{tabular}{cccccc}
\hline No & No Sampel & Vitrinite (\%V) & $\begin{array}{c}\text { Liptinite }(\% \\
\text { V) }\end{array}$ & Inertinite (\%V) & Mineral (\%V) \\
\hline 1 & $2 \mathrm{P} / 1 / 16$ & 58.00 & 2.6 & - & 39.40 \\
2 & $3 \mathrm{P} / 1 / 16$ & 52.24 & 2.6 & - & 45.16 \\
3 & $4 \mathrm{P} / 1 / 16$ & 89.00 & 4.6 & - & 6.40
\end{tabular}

\section{Conclusions}

coal composition by microscopic investigation, the type of organic matter derived from the wet marsh plants (High GI, Low TPI) or limnic conditions. whereas the spread in the form of pyrite mineral frambiodal lines indicate the condition of surface water is high on the surface layer of peat (High GWI, Low VI) or rheotropic mire. the above interpretation is also supported by the absence of fungal growth.
[10] Styan, W.,B., \& Bustin, R.M., (1983), Petrography of some Fraser Delta Peat Deposits: Coal Maceral and Microlithoty Peprecursors IntemperateClimatepeats. International Journal of Coal Geology, 2, 321-370

\section{References}

[1] Barber, M. J. Crow, J. S. Milsom. (2005). Sumatra Geology, Resources and Tectonic Evolution (Geological Society Memoirs, No. 31) - Geological Society of London .p86 - 97.

[2] Calder, J.H., Gibling, M.R. and Mukhopadhyay, P.K. (1991) Peat formation in a Westphalian B piedmont setting, Cumberland Basin, Nova Scotia: implications for the maceral-based interpretation of rheotrophic and raised paleo-mires. Bulletin de la Société Géologique de France 162, 283-298.

[3] Diessel, C.F.K. (1986) On the correlation between coal facies and depositional environment. Proc. 20th Symp. Dept. Geol., University of Newcastle, NSW, pp. 19-22.

[4] ICCP Training Course on Dispersed Organic Matter (2011).Organic Petrology, Macerals, Microlithotypes, Lithotypes, Minerals, Rank. Departamento de Geociências, Ambiente e Ordenamento do Território, Faculdade de Ciências da Universidade do Porto Porto, Portugal

[5] ICCP (2001) The new inertinite classification (ICCP System 1994). Fuel, v.80, pp.459-471.

[6] Suárez-Ruiz Isabel Organic Petrology: An Overview. Instituto Nacional del Carbón (INCAR-CSIC) Oviedo Spain. pp.201 - 224.

[7] Isabel Suárez-Ruiz Deolinda Flores, João Graciano Mendonça Filho, Paul C. Hackley d(2012). Review and update of the applications of organic petrology: Part 1, geological applications. International Journal of Coal Geology 99 (54-11).

[8] Komang Anggayana, Basuki Rahmad, H. H. Arie Naftali and Agus Haris Widayat. Limnic Condition in Ombrotrophic Peat Type as the Origin of MuaraWahau Coal, Kutei Basin,

[9] Indonesia. Journal Geological Society Of India Vol.83, May 2014, pp.555-562. 